\title{
Bookshelf 2016
}

\author{
Richard Price and Sally Price \\ Anse Chaudière, 97217 Anses d'Arlet, Martinique \\ rixsal@gmail.com
}

We begin once again by expressing our gratitude to all the reviewers who have, collectively, provided such a rich resource for keeping up with writing on the region. At the same time, we must lament the fact that some of the people who've accepted a book and promised to review it have, despite a series of gentle reminders over a year or two, never shared their reactions to the book with NWIG readers. With our apologies to the authors of books that have therefore not been given their due in these pages, we simply list them here. Eleven reviews we had intended to publish:

City of Islands: Caribbean Intellectuals in New York, by Tammy L. Brown (Jackson: University Press of Mississippi, 2015, cloth US\$60.00)

The Fortunes of Frances Barber: The True Story of the Jamaican Slave who Became Samuel Johnson's Heir, by Michael Bundock (New Haven CT:Yale University Press, 2015, cloth US\$35.00)

To Defend the Revolution Is to Defend Culture: The Cultural Policy of the Cuban Revolution, by Rebecca Gordon-Nesbitt (Oakland CA: PM Press, 2015, paper US\$24.95)

Final Passages: The Intercolonial Slave Trade of British America, 1619-1807, by Gregory E. O'Malley (Chapel Hill: University of North Carolina Press, 2014, paper US\$27.95)

Healthcare without Borders: Understanding Cuban Medical Internationalism, by John M. Kirk (Gainesville: University Press of Florida, 2015, cloth US\$79.95)

Urban Space as Heritage in Late Colonial Cuba: Classicism and Dissonance on the Plaza de Armas of Havana, 1754-1828, by Paul Niell (Austin: University of Texas Press, 2015, cloth US\$55.00)

Geographies of Cubanidad:Place, Race, and MusicalPerformance in Contemporary Cuba, by Rebecca M. Bodenheimer (Jackson: University Press of Mississippi, 2015, cloth US\$60.00)

Shine: The Visual Economy of Light in African Diasporic Aesthetic Practice, by Krista A. Thompson (Durham NC: Duke University Press, 2015, paper US\$24.95)

Electric Santería: Racial and Sexual Assemblages of Transnational Religion, by Aisha M. Beliso-de Jesús (New York: Columbia University Press, 2015, paper US\$30.oo)

(C) RICHARD PRICE AND SALLY PRICE, 2017 | DOI: 10.1163/22134360-09101055

This is an open access article distributed under the terms of the Creative Commons 
Non-Sovereign Futures? French Caribbean Politics in the Wake of Disenchantment, by

Yarimar Bonilla (Chicago: University of Chicago Press, 2015, paper US\$27.50)

Changing the Subject: Writing Women across the African Diaspora, by Merinda Simmons

(Columbus: Ohio State University Press, 2014, cloth US\$51.95)

Adding to the list of unreviewed books is an unfortunately large number for which we valiantly tried to find a reviewer (asking five or more specialists) but found no takers. We list them here:

Plus jamais esclaves! De l'insoumission à la révolte, le grand récit d'une émancipation (1492-1838), by Aline Helg (Paris: La Découverte, 2016, paper $€ 26.00$ )

De l'esclavage à la liberté forcée: Histoire des travailleurs africains engagés dans la Caraïbe française au XIXe siècle, by Céline Flory (Paris: Karthala, 2015, paper € 27.00) Huareo: Story of a Jamaican Cacique, by Fred W. Kennedy (Kingston: Ian Randle, 2015, paper US\$34.95)

Birth Control in the Decolonizing Caribbean: Reproductive Politics and Practice on Four Islands, 1930-1970, by Nicole Bourbonnais (Cambridge: Cambridge University Press, 2017, cloth US\$99.99)

Island at War: Puerto Rico in the Crucible of the Second World War, by Jorge Rodríguez Beruff \& José L. Bolívar Fresneda (Jackson: University Press of Mississippi, 2015, cloth US\$65.00)

Performance and Personhood in Caribbean Literature: From Alexis to the Digital Age, by Jeannine Murray-Román (Charlottesville: University of Virginia Press, 2016, paper US\$27.50)

The Colonial System Unveiled, by Baron de Vastey, edited by Chris Bongie (Liverpool: Liverpool University Press, 2014, cloth US\$120.00)

And there is an even longer list of books, mostly destined for Bookshelf, that we requested from publishers that never reached us:

Breach of Trust/Abuso de confianza, by Ángel Escobar (Tuscaloosa: University Alabama Press, 2016, paper US\$19.95) [Cuban poetry]

Goldeneye: Where Bond Was Born: Ian Fleming's Jamaica, by Matthew Parker (New York: Pegasus, 2016, paper US\$16.95)

Cuba La Lucha, by Carl De Keyzer (Tielt, Belgium: Lannoo, 2016, cloth US\$59.95) [photos]

Castro's Cuba: An American Journalist's Inside Look at Cuba, 1959-1969, by Lee Lockwood (Cologne, Germany: Taschen, 2016, cloth US\$69.99)

The Yard, by Aliyyah Eniath (Delhi, India: Speaking Tiger Books, 2016, paper US\$20.oo)

[East Indian life in Trinidad] 
Puerto Rican Light (Cueva Vientos), by Allora y Calzadilla with Jessica Morgan, Sharon Beder \& Franco Berardi (New York: Dia Art Foundation, 2016, paper US\$29.95)

The Art of the Cayman Islands: A Journey through the National Gallery Collection, by Natalie Urquhart (New York: Scala Art Publishers, 2016, cloth US\$35.00)

A Bloom of Stones: A Tri-lingual Anthology of Haitian Poems After the Earthquake, edited by Kwame Dawes (Leeds, U.K.: Peeple Tree, 2016, paper US\$39.95)

Only the Road/Sólo el Camino: Eight Decades of Cuban Poetry, edited by Margaret Randall (Durham NC: Duke University Press, 2016, paper US\$28.95)

Concrete Cuba: Cuban Geometric Abstraction from the 1950s, by Abigail McEwen \& Susanna Temkin (New York: David Zwirner Books, 2016, cloth US\$55.0o)

Cuba Unfinished: Photographs 1989-2015, by Manuello Paganelli (n.p.: Daylight Books, 2016, cloth US\$6o.oo)

Havana, by Bernhard Hartmann (Kempen, Germany: teNeues, 2016, cloth US\$65.00) [photos]

Leaving Atlantis, by Esther Phillips (Leeds, U.K.: Peepal Tree, 2016, paper US\$17.95) [poetry]

Iconocracia: An Image of Power and the Power of Images in Contemporary Cuban Photography, by Iván Nuez (Madrid: Turner Ediciones, 2016, cloth US\$30.00)

Creole Kitchen: Sunshine Flavors from the Caribbean, by Vanessa Bolosier (San Francisco: Weldon Owen, 2016, cloth US\$35.00)

sankofa:blood.claat, benu, andword!sound! powah! by d'bi. young anitafrika ([Toronto]: Playwrights Canada Press, 2016, paper US\$26.95)

The Clearing Paperback, by Dan Newman (n.p.: Diversion Publishing, 2016, paper US\$14.99) [about St. Lucia by a boy, not native but partly brought up there]

Wifredo Lam: Imagining New Worlds, edited by Elizabeth Goizueta (Boston: McMullen Museum of Art, Boston College, 2014, paper US\$40.00)

Poetry of Haitian Independence, edited by Doris Y. Kadish \& Deborah Jenson (New Haven CT: Yale University Press, 2015, cloth US\$40.00)

After the Dance: A Walk through Carnival in Jacmel, Haiti, by Edwidge Danticat (New York: Vintage, 2015, paper US\$14.95)

Imagining New Worlds: Wifredo Lam, José Parlá, and Fahamu Pecou, by José Parlá (Bologna, Italy: Damiani, 2015, paper US\$29.95)

In Fine Style, The Dancehall Art of Wilfred Limonious, by Christopher Bateman \& $\mathrm{Al}$ Fingers (London: One Love Books, 2015, cloth US\$45.00)

The Yankee Comandante: The Untold Story of Courage, Passion, and One American's Fight to Liberate Cuba, by Michael Sallah \& Mitch Weiss (Guilford CT: Lyons Press, 2015, cloth US\$26.95)

Thony Belizaire, Witness to History: 100 Photographs of the Struggle for Democracy in Haiti, by Thony Belizaire (New York: Seven Stories Press, 2015, cloth US\$39.95) The Distant Marvels, by Chantel Acevedo (New York: Europa Editions, paper US $\$ 17.00$ ) 
God Loves Haiti, by Dimitry Elias Léger (New York: Amistad, 2016, paper US\$15.99) Jules Chin A Foeng, by Paul Faber (Utrecht: LM Publishers, 2015, paper €19.50).

Dictionary of Caribbean and Afro-Latin American Biography, edited by Franklin

W. Knight \& Henry Louis Gates Jr (New York: Oxford University Press, 2016, cloth US\$1,195.00)

Leadership in the Cuban Revolution: The Unseen Story, by Antoni Kapcia (Manchester,

U.K.: Manchester University Press, 2014, paper US\$29.95)

Dangerous Moves: Politics and Performance in Cuba, by Coco Fusco (London: Tate Modern, 2015, cloth US\$37.50)

The Origin, Development and Diffusion of the Steel Band in the Caribbean and Beyond:

The Historical Geography of a Musical Instrument, by Ralph L. Parris (Lewiston NY:

Edward Mellen Press, 2015, cloth US\$139.95)

We would like to point Caribbeanists toward www.repeatingislands.com, where, every day, Ivette Romero-Cesario and Lisa Paravisini-Gebert post numerous announcements (with links to original sites) about Caribbean culture, literature, and the arts. We know no other website that is as comprehensive on subjects of interest to our readers. We thank Repeating Islands for making us aware of various Caribbean publications that we would otherwise have missed.

We begin with this year's Bookshelf with a rich crop of fiction, presented in no particular order.

Curaçaoan novelist Tip Marugg's The Roar of Morning (De morgen loeit weer aan), first translated by Paul Vincent and published in 2004 in the Faber Caribbean Series, has now been republished by Yale University Press (2015, US\$16.oo), making this dark, thoughtful, apocalyptic, magical-realist-Caribbean work once again available to an Anglophone audience.

Two short story collections from pioneer West Indian novelists of succeeding generations. A fifth volume of writings by Alfred Mendes edited by Michèle Levy, Alfred H. Mendes: Short Stories, Articles, and Letters (Kingston: University of the West Indies Press, 2016, paper US\$40.oo), includes thirteen stories (six previously unpublished and several dating from his time in the United States) plus some two dozen pieces of journalism, largely from the Trinidad Guardian, and two letters from George Padmore. This friend of C.L.R. James and member of the Beacon group of the 1930 s wrote a torrent of short stories, and Levy's latest collection adds to the available mix. John Hearne's Short Fiction, edited by his daughter Shivaun Hearne, with a foreword by Marlon James and an introduction by Kim Robinson-Walcott (Kingston: University of the West Indies Press, 2016, paper US\$20.00), permits a new consideration of this major Jamaican writer's shorter work, mainly from the late 1950s, includ- 
ing Sid Mintz's favorite, "The Mongoose who Came to the City" and that of Derek Walcott (and ourselves), "At the Stelling," dating from his time in British Guiana.

The Marvellous Equations of the Dread: A Novel in Bass Riddim, by Marcia Douglas (Leeds, U.K.: Peepal Tree, 2016, paper $£$ 9.99), plunges us into a magicopoetic world where Nanny of the Maroons meets Marcus Garvey, where Bob Marley reasons with the H.I.M. (The Lion of Judah) in Zion, and where the singer and a deaf girl called Leenah are the main protagonists, with cameo appearances by an enslaved boy hanged in the eighteenth century and streetcorner madmen in the Babylon of modern Kingston. This is one Half Way Tree-centered ganja-hazed novel, thick with Jamaican words and images, a Rastafantasma of a book.

Jacob Ross's engaging new novel, The Bone Readers (Leeds, U.K.: Peepal Tree, 2016, paper £ 9.99), takes place in a thinly-disguised Grenada, offering a rich evocation of place, sharply-drawn characters (each speaking a different register of English), and genuine suspense. In turning cold cases hot, Detective Constable Michael (Digger) Digson - just back from a year in England studying forensics-uses his remarkable skills in reading people as well as bones to unearth the darker secrets of a Spiritual Baptist congregation and of the police force itself. It's a compelling read.

The narrator of Patricia Engel's new novel, The Veins of the Ocean (New York: Grove Press, 2016, paper, US\$25.00), weaves in and out of her life in Miami and the Florida Keys, childhood visits with her grandmother in Cartagena, and discovery of Yemayá and other deities (first through the stories of her Cuban boyfriend and then in Havana). Memories of her older brother who died in a solitary cell on death row beat rhythmically through the narrative, feeding into broader reflections about the costs of freedom deprived. The book lives up to the praise for her earlier books by Edwidge Danticat, Junot Díaz, Michiko Kakutani, and others.

Nicole Dennis-Benn's debut novel, Here Comes the Sun (New York: Liveright, 2016, cloth US\$26.95), offers a vivid portrayal of, as Marlon James puts it, "women pushed to the edge"-rural Jamaican women honing survival skills on the island's fast-changing touristophilic north coast. Strong family loyalties, anxieties about race and color, the inevitability of linking sex and money for women with little of the latter, and the social ostracism of women who love women weave through this well-plotted story. It's a page-turner that captures the complex pathos of modern Caribbean realities.

The narrator of Trinidadian Kevin Jared Hosein's The Repenters (Leeds, U.K.: Peepal Tree Press, 2016, € 9.99) recounts his relationships growing up in a Catholic orphanage, followed by his experiences in the underbelly of Port-of- 
Spain. Told with empathy and humor in Trini speak, the brief novel succeeds in bringing its main character, and others around him, to life.

In The Pain Tree (Toronto: Cormorant Books, 2015, paper, US\$22.95), veteran author Olive Senior treats us to ten short-story gems (revised from earlier published versions) that amply confirm the book's selection as winner of the 2016 OCM Bocas Prize for Caribbean Literature. Delving into personal relations in a variety of Jamaican settings, the stories are touching portrayals of individuals driven, in often comical combinations, by lust, jealousy, arrogance, and duplicity but always in ways that make us smile in sympathy with even their most extreme foibles. Wonderful writing that succeeds in capturing the flavor of its protagonists' worlds. The story titled "A Father Like That" took our breath away.

The Gymnast and Other Positions, by Jacqueline Bishop (Leeds, U.K.: Peepal Tree, 2015, paper £12.99) offers ten short stories, ten largely autobiographical essays on her life as a writer of novels and poetry (but also on Roger Mais's Black Lightning and on Claude McKay's time in Morocco, where he wrote much of his important work), and ten interviews that others have conducted with her about being a painter, writer, and founding editor of Calabash: AJournal of Caribbean Arts and Letters. Taken together, a mid-life stock-taking by a talented Jamaican who lives in New York. Winner of the 2016 OCM Bocas Prize for Caribbean Nonfiction.

Karen Lord, editor of New Worlds, Old Ways: Speculative Tales from the Caribbean (Brooklyn NY: Peekash Press [a joint transatlantic imprint of Peepal Tree and Akashic], 2016, paper US\$17.95), defines speculative fiction as "an umbrella term for science fiction, fantasy, and several other subgenres of improbable what-ifs." Featuring mostly-young writers from Trinidad \& Tobago, Barbados, and Bermuda, these tales run from flying robots made by the police to the exploits of sea-turtle-women, with strong local color throughout. An interesting read.

La Americana (New York: Skyhorse Publishing, 2016, cloth US\$19.99) is Melanie Bowden Simón's chick-lit-style memoir featuring a 25-year-old all-American Southern girl who, weeks after losing her mother to cancer, steps off the plane for a vacation in Cuba, falls in love with her taxi driver, and after many separations and much heartache, marries her man and settles with him in Savannah, Georgia-but not before readers get generous splashes of Cuban local color, from salsa clubs to Santería.

Addeah Palmer's debut novel (really a novella), Macca Tree Manns (Kingston: Ian Randle, 2015, paper US $\$ 12.00$ ), offers a cute story set in rural Jamaica, good patois dialogue, occasional wicked humor, the whole marked by uneven writing — but overall, kinda fun. 
We found the short stories collected in San Juan Noir, edited by Mayra Santos-Febres (Brooklyn NY: Akashic, 2016, paper US\$15.95), somehow less compelling than those in Akashic's Haiti Noir and Kingston Noir (reviewed favorably in Bookshelf 2011 and 2012), though chock full of the requisite local color, gore, and lowlives.

Évelyne Trouillot's Memory at Bay (Charlottesville: University of Virginia Press, 2015, paper US\$24.50) is Paul Curtis Dow's translation of La mémoire aux abois, winner of the 2010 Prix Carbet de la Caraïbe et du Tout-Monde. The story is told through two interior monologues in dialogue, set in a Paris hospital room - the interior voice of the aged, dying widow of Papa Doc and that of the young Haitian nurse who, with her family, suffered so much under the dictator's rule. The first-vain, sadistic, self-justifying - recounts from her perspective her late husband's triumphs. The second, addressed to her own dead mother, evokes in detail the horrors they experienced. A strong, moving meditation on memory, loss, evil, and courage. A memorable book.

Renowned Haitian poet and novelist René Depestre celebrated his ninetieth birthday earlier this year with the publication of Popa Singer (Paris: Zulma, 2016 , paper $€ 16,50$ ), a magical realist satirical account, based in part (according to interviews he's given) on lived experience, including a $195^{8}$ meeting with Papa Doc, who had lived near him as a youth in Jacmel. The book centers on Depestre's mother, named after the sewing machine she used so effectively as a weapon.

Makenzy Orcel's L'Ombre animale (Paris: Zulma, 2016, paper €20.00) opens in the voice of a female cadaver, who narrates throughout 335 pages without benefit of a single period but with an evocative tale of rural Haitian life that morphs into a polar-like Port-au-Prince sequel. It has won at least four literary prizes.

Zulma has also published new editions of three of Dany Laferrière's powerful Haitian novels: L'odeur de café, Le charme des après-midi sans fin, and Le cri des oiseaux fous (each 2016, paper $€$ 9.95). We should also signal a new edition of Marie Vieux-Chauvet's classic anti-Duvalierist novel, Amour, colère et folie (Paris: Zulma, 2015, paper $€ 11.20$ ), with a moving introduction by Laferrière.

Self-described "ethno-psychoanalyst," Martiniquan-born Simonne Henry Valmore's new novel, Un petit matin (La Roque d'Anthéron, France: Vents d'ailleurs, 2015, paper, $€ 16.00$ ), takes off from the real-life discovery by a young boy, on a beach in Martinique in 1934, of the lifeless body of André Aliker, journalist and political activist, assassinated for his investigative writings. Imagining what happened to that boy, as revealed through his fictional conversations with Jacques Lacan nearly half a century later, makes up the core of this slim, dark tale. 
In La matière de l'absence (Paris: Seuil, 2016, paper €21.0o), the incontournable Patrick Chamoiseau offers a series of meandering philosophical reflections on death (composed in the form of largely one-way conversations with his eldest sister, La Baronne) - centered on that of their mother, Man Ninotte, replete with numerous, often touching childhood reminiscences, but quickly turning to such subjects as wakes, conteurs, zombies, gravediggers, the eruption of Mont Pelée, conques de lambis, marronage and resistance, bèlè, l'esprit jazz, the Middle Passage, and the history of humanity, with multiple nods to Glissant, la Relation and le Tout-monde. We offer a sample passage, from near the end of the book, so you get the idea: "La globalisation du monde a entraîné la rencontre (massive, accélérée) de peuples fragmentés, de civilisations fragmentées, de cultures fragmentées, d'imaginaires fragmentés, d'individus emportés dans un maelström anthropologique bien plus complexe que le simple métissage. Chocs. Hybridations, synthèses, symbioses, répulsions, antagonismes et interdépendances se produisent sans fin. Ce maelström anthropologique et environnemental s' appelle la créolisation ... Le véritable nègre marron, le nègre marron fondamental, tout comme l'était Glissant, n'était donc pas celui qui s'enfuyait à la recherche de nouvelles certitudes ou d'une mise en transparence du monde, mais celui qui avait le courage, via le Tout-monde ... d' accepter le grand mystère relationnel et de se confronter à l'irrécusable de ce qu' il ne pouvait pas envisager de comprendre" (pp. 288-89). We would not dare to translate.

Colin Niel's nearly 50o-page French-language novel Obia (Arles, France: Rouergues, 2016, paper $€ 23.00$ ) is a strange beast. Like his previous two books, it is published as a polar (French crime thriller/detective novel) set in and around Saint-Laurent-du-Maroni and it again features the fictional André Anato, a Ndyuka gendarme (Special Investigations) who was raised in metropolitan France. As we said of Niel's first, Les hamacs de carton (see "Bookshelf 2012"), one rarely reads a novel with such rich and accurate local color-the multiethnic complexities of the town and its hinterland are fully explored. Niel has done his homework, drawing extensively and usefully on the several books (including our own) and the scholars and officials thanked in his acknowledgments, as well as his own experience in Guyane. But we have doubts that the plot, dialogue, and characters will hold the interest of general readers. Nevertheless, for those who are looking for an introduction to the realities of Guyane, from life inside its central prison and its police force to that in the shacks of illegalimmigrant Surinamers fleeing the long shadow of the civil war along the Route de Mana, it's worth a read.

Nègre Marron: Itinéraire d'un enfant du ghetto, a début novel by Jessi Américain (Matoury, Guyane: Ibis Rouge, 2016, paper $€ 15$.00), begins in this same world - the Maroon "ghettos" of Saint-Laurent (with petty crime and interna- 
tional drug mules, as well as warm family life). But, as a partly autobiographical work by a young Aluku (Boni), it has the advantage of being an inside job. The central protagonist, like the author, manages against all odds to be successful at school, eventually winning a scholarship to the prestigious Sciences Po in Paris, where he discovers a whole new world and then spends a year studying in Colombia. Though written as third-person fiction, it reads more like a memoir — not particularly successful as literature but largely believable.

Turning to poetry, "swept away" understates our reaction to Morning, Paramin (New York: Farrar, Straus \& Giroux, 2016, cloth US\$35.00), a collaboration between Derek Walcott and Peter Doig. Inspired by the paintings of his Scottish-born, Canadian-raised, Trinidad-residing friend, the Caribbean master pens a poem facing each artwork. Astonishing, personal, honest, and wondrous-spend some time with this one.

We must thank Peepal Tree for publishing (in its Caribbean Modern Classics series) Victor D. Questel's Collected Poems (2016, paper £12.99), bundled with a 100-plus-page essay, “'These Collapsing Times': Remembering Q," by Gordon Rohlehr. Questel, who died suddenly at age 33 in 1982, was the first Ph.D. in Literature at UWI St. Augustine, with a thesis on Derek Walcott. And the influence of that poet, as well as Kamau Brathwaite (and George Lamming, Wilson Harris, and otherWest Indian literary giants of the previous generation), shows strongly in the three collections of poems, previously published separately in Trinidad. The poems are truly rich (personally, culturally), well worth spending time with, and Rohlehr's close readings enhance the experience.

Hiroona: An Historical Romance in Poetic Form, by Reverend Canon Horatio Nelson Huggins, edited by Désha A. Osborne (Kingston: University of the West Indies Press, 2015, paper US\$40.00), republishes a rare, early Caribbean literary work, written in the late nineteenth century by a St. Vincent-born Anglican priest. With more than 9,0oo lines of rhyming verse, Hiroona recounts in fictionalized form the Second Carib War of 1795-97, which ended with the forced transportation of the "Black Caribs" to Central America. A 32-page introduction and extensive notes situate the poem in its historical and literary context.

Absolute Solitude: Selected Poems, by Dulce Maria Loynaz, translated by James O'Connor (Brooklyn NY: Archipelago, 2016, paper US\$18.00), brings together in facing-page Spanish-English texts, selections from the Cuban poet's collections of prose poems, Poems without Names and Autumn Melancholy, some only one line long, others just more than a page. Her story is well known - aristocratic lawyer, novelist, and poet who went into self-imposed interior exile after the Revolution and reemerged to fame and new-found cre- 
ativity with the Spanish Royal Academy's 1992 Cervantes Prize, when she was 90- these poems have the purity and perfection of her interior, but in many ways universal, world.

Nothing Out of This World: Cuban Poetry 1952-20oo, edited and translated by Katherine Hedeen (Ripon, U.K.: Smokestack Books, 2016, paper US\$22.00), is intended as a follow-up to Cintio Vitier's $195^{2}$ Cinquenta años de poesia cubana, 1902-1952, and presents selected poems by 36 Cubans writing in the second half of the twentieth century, some of whom will be familiar to many readers of this journal (Miguel Barnet, Nancy Morejón, Heberto Padilla, Roberto Fernández Retamar), and others who are younger and less well known. Overall, a real pleasure.

Having been smitten last year by her novel, Land of Love and Drowning (see "Bookshelf 2015"), we were eager to read Tiphanie Yanique's first poetry collection, Wife (Leeds, U.K.: Peepal Tree, 2015. paper £ 8.99). Winner of the Felix Dennis Prize for Best First Collection 2016, it does not disappoint. Poems about marriage that make you think, as well as laugh. A very special female Virgin Islands sensibility.

Cannibal (Lincoln: University of Nebraska Press, 2016, paper US\$17.95) is Montego-Bay-born Safiya Sinclair's prize-winning debut collection, remarkable for its intelligence, its muscular lyricism, its postcolonial critique, and its consistently engaging style. Caliban is omnipresent in these luminous reflections on Jamaica, Virginia (in Jefferson's day and now), and exile. Highly recommended.

Port Antonio-born Ishion Hutchinson's new collection, House of Lords and Commons (New York: Farrar, Straus \& Giroux, 2016, cloth US\$23.00), offers serious, sometimes hermetic thoughts about happiness, loss, and the lure of the sea, presented in lyrical, almost-Walcottian cadences. Whether evoking Jamaica, Venice, or Florence, they remain anchored in the postcolonial Caribbean, learned and resonant.

In Measures of Expatriation (Manchester, U.K.: Carcanet, 2016, paper US\$15.99), Vahni Capildeo offers a volume of prose-poems and poems that meditate on her childhood in Port-of-Spain, her winters in Oxford, and travels in Europe. By turns arch, personal, and critical of simple notions of identity, her poems interrogate expatriation in the wake of Empire.

Paulette A. Ramsay's Star Apple Blue and Avocado Green (Kingston: Ian Randle, 2016, paper US\$10.95) presents 62 Jamaica-inflected poems.

In Book of the Dead (Philipsburg, St. Martin: House of Nehesi, 2016, paper US\$20.0o), Lasana Sekou once again takes off from his beloved St. Martin to explore other Caribbean sites and oppressed peoples as far away as the Middle East with his spare but heartfelt protest poetry. 
Haitian-born Anthony Phelps, laureate of the 2016 Prix Carbet de la Caraïbe et du Tout-Monde for his life work as poet, novelist, and playwright, did time in Papa Doc's prisons before settling in Montreal. Author of a large number of literary works, his most recent poetry collections are Nomade je fus de très vieille mémoire (Paris: Éditions Bruno Doucey, 2012, paper $€ 18.20$ ) and Je veille, incorrigible féticheur (Paris: Éditions Bruno Doucey, 2016, paper $€ 15.00$ ).

Some diverse nonfiction not otherwise reviewed in NWIG:

Late last year, we received an email that began, "My name is Quincy Saul, and I am a co-editor of a book by US political prisoner Russell 'Maroon' Shoatz, who draws substantially from your work ... It is both a history book about maroons, and takes the historical maroons as an example and model for modern-day movements for freedom and justice." Soon the book itself arrived: Maroon the Implacable: The Collected Writings of Russell Maroon Shoatz, edited by Fred Ho \& Quincy Saul (Oakland CA: PM Press, 2013, paper US\$20.oo). Shoatz was a founding member of the Black Panther Party, convicted of killing a police officer, given multiple life sentences, and has now been incarcerated for over 40 years, more than 20 in solitary confinement. Having twice escaped from maximum-security prisons, earning the nickname Maroon, he became interested in the role of Maroons in black resistance-his prison writings, composed under unspeakable conditions, hold up America's shame for all to see. As Amiri Baraka says on the cover, "This book is that very funky instruction manual on how to make revolution."

Haiti et l'identité littéraire trans-caribéenne, by Emilio Jorge Rodríguez (Philipsburg, St. Martin: House of Nehesi, 2013, paper US\$25.00), presents several essays by this Cuban literary critic and Haitian specialist as a bridge toward greater Cuban-Haitian cultural relations.

In Soualiga Catholica: St. Martin of Tours Parish (1841-2016) (Philipsburg, St. Martin: House of Nehesi, 2016, paper US\$20.00), parish priest Gerard van Veen celebrates the 175th anniversary of its founding with minibiographies of former pastors, descriptions of buildings owned by the Church, and more.

The catalogue to a monumental exhibition, The EY Exhibition: Wifredo Lam, edited by Catherine David (London: Tate Enterprises, 2016, paper US $\$ 45.00$, following on a 2015 French edition published in Paris by the Centre Pompidou), opens with the assertion that "Wifredo Lam was the most internationally famous painter to emerge from Cuba." The following 240 pages show what an understatement this is. Lam's art was nourished in multiple environments, from Havana and Martinique to Madrid, Barcelona, Paris, and rural Italy, and by strong relationships with Pablo Picasso, André Breton, and other central players in what the catalogue calls "global modernism." Essays by Lam scholars such as Lowery Stokes Sims (on Lam's "post-modern modernism") and Kobena 
Mercer (on Lam's "syncretic vitalism"), together with older ones by Lam friends such as Michel Leiris and Fernando Ortiz, contextualize the lavishly illustrated, 240-page volume.

We're apparently not the only enthusiasts of Caribbean art who've missed encountering the work of Andrew Lyght-neither Veerle Poupeye (in Caribbean Art) nor Richard Powell (in Black Art and Culture in the 2oth Century) mention him. It was with pleasure, then, that we read the exhibition catalog for Andrew Lyght-Full Circle at the Samuel Dorsky Museum of Art at SUNY New Paltz (Albany: SUnY Press, 2016, paper, US\$ 45.00), and discovered the work of this Guyana-born and -raised artist who has spent much of his life in Montreal and then New York, punctuated by residencies in Italy and time in Paris. The essays on the development of his approaches to art (many of them authored by Lyght) are all interesting, as is the photographic record of his eclectic artistic expression, which "adopts the language of abstraction and linear forms exploring the limits of pictorial space" (p. 6).

LeGrace Benson, who discovered and fell in love with Haiti as an American college student in the 1950s, has devoted her life to the study of Haitian art and culture. Weighing in at over 300 densely written pages, her 2015 book, Arts and Religions of Haiti: How the Sun Illuminates under Cover of Darkness (Kingston: Ian Randle, cloth US\$150.00), sets out the results of her research on the whole range of Haitian arts in the context of their religious and cultural roots. Dating of the 252 artworks illustrated would have been an embellishment to the work.

Cuba: Black and White (Göttingen, Germany: Steidl, 2015, cloth US\$6o.oo) is a beautiful record of American photographer Anna Mia Davidson's fascination with Cuba, beginning in 1999. Nearly a hundred stunning black-and-white images catch Cubans flirting, napping, dancing, doing the laundry, playing dominoes, getting haircuts, feeding pigs, playing soccer, watching TV, getting married, and more. The half dozen images devoted to maternity clinics reflect her special admiration for this struggling country's healthcare system, which produces one of the lowest rates of infant mortality in the world.

Mark Kurlansky, author of a couple of dozen books (including some best sellers), turns his affectionate gaze on a city he's often visited during the past 30 years. Havana: A Subtropical Delirium (New York: Bloomsbury USA, 2017, cloth US\$26.0o) is a somewhat rambling, often glib tour through the capital's history and architecture, with frequent literary asides and citations, diverse local recipes, and commentary on everything from politics to baseball. On the whole, shallow and unsurprising, if easy to read.

The Banjo:America's African Instrument (Cambridge MA: Harvard University Press, 2016, cloth US\$29.95) is Laurent Dubois's love letter to an instrument, 
to the idea of creolization, and in a sense to the country he was brought to by his Belgian parents as a child. Years in the making, The Banjo is filled with research and anecdotes, moving from the history and distribution of diverse African chordophones through their widespread Caribbean descendants and on to their North American counterparts and performers. There are small (and unimportant) errors of detail—for example, Dutch Suriname had not become the British colony of Berbice by 1828 , the Prices did not find the "Creole bania" collected by Stedman in the 179os in the Rijksmuseum in Amsterdam (we found it in the Rijksmuseum voor Volkenkunde in Leiden), and the Stedman plate showing the instrument is reversed (because he uses the erroneous French edition rather than the original English one). But overall, the book is a joyful, personal romp through an exemplary material testimony of Atlantic history, with important observations about twentieth-century U.S. race relations and politics, and a fine closing section on Pete Seeger, the folk revival, and the banjo's enduring role.

Dénètem Toaum Bona's Fugitif, où cours-tu? (Paris: Presses Universitaires de France, 2016, paper $€ 12.00$ ) collects several previously published articles that the author describes as "philosophical and literary essays about marronage and resistance." Predictable allusions to Foucault, Fanon, and Glissant are set side by side with personal observations on the Aluku commune of Apatou in Guyane and on Mayotte, where he teaches philosophy. Bibliographic references are restricted to the French language.

Like so much of Fanon scholarship, Peter Hudis's Frantz Fanon: Philosopher of the Barricades (London: Pluto, 2015, paper US\$20.00) is strongest on the Algerian years. Discussion of Fanon's early life and lead-up to Black Skins, White Masks focuses on the influence of European philosophers-from Hegel through Husserl to Sartre-and does scant justice to the realities of the Martinique he experienced during his first 17 years. Hudis claims, for example, that "gradations of skin color of those [Martiniquans] of African descent did not carry the same degree of social significance as found elsewhere," while we know of nowhere on earth where they are (and were in Fanon's day) more significant. Or again, his remarks about Fanon's critique of Mayotte Capécia ignore the raft of relevant recent scholarship (much of it discussed in a review by A. James Arnold in NWIG 74-3\&4 [2000]). And readers of this journal may be irritated by the author's frequent references to the French Antilles as "the West Indies" and to Guyane (French Guiana) as "Guiana." One can conclude that Hudis is more musical about philosophy and radical politics than about the Caribbean.

Black London: The Imperial Metropolis and Decolonization in the Twentieth Century, by Marc Matera (Berkeley: University of California Press, 2015, paper 
US\$29.95), focuses on the interwar years, devoting a number of interesting pages to the role of Bronislaw Malinowski's LSE seminars in influencing future African leaders. The book seems stronger on politics, music, gender, and sexuality than on literature or the arts. Overall, a good read.

Encountering Difference, by Robin Chen \& Olivia Sheringham (London: Polity, 2016, paper $£_{15.99)}$ ), gives a rather didactic answer to Stuart Hall's question-for-the-21st-century: "How are people from different cultures, [etc.] ... to make some sort of common life together without retreating into warring tribes ... insisting that other people must look exactly like you ... think exactly like you?" It explores the way concepts such as nationalism, cosmopolitanism, diaspora, and creolization play out in such locations as Mauritius, Cape Verde, Louisiana, and Martinique. The latter chapter, while a reasonable survey of local identitarian dilemmas, does little to suggest solutions, but perhaps the authors' modest explorations can foster thought toward making our diasporic, creolized world a bit more livable.

Afro-Mexican Constructions of Diaspora, Gender, Identity and Nation, by Paulette A. Ramsay (Kingston: University of the West Indies Press, 2016, paper US\$30.oo), examines cultural expressions, mainly literary (largely oral materials), produced by the black people who live along the Pacific coast of Guerrero and Oaxaca. Her culminating argument is that these largely un-mestizoized descendants of enslaved Africans share, in their cultural productions (poetry, folktales), a fully "Caribbean" aesthetic.

We had asked Gert Oostindie to review Matthew Parker's, Willoughbyland: England's Lost Colony (London: Windmill Books, 2015, paper £9.98), but on reading it "cover to cover in less than a day" - the blurb says "Popular history at its best"-he concluded that it's more appropriate for mention in "Bookshelf." He wrote: "There's little scholarly ambition, it's a chronological narrative starting (and ending) with hopes of El Dorado (De Berrio, Walter Ralegh) and then moving to Francis Willoughby's project of converting the Guianas and particularly Suriname into his private plantation colony. There is a nice chapter about Aphra Behn, but the rest of the book is pretty much political and military history, ending with the Dutch take-over. Well-written, nice anecdotes, a lively narrative, but not very deep either, nor anything particularly new. In sum, a nice read for beginners."

Caribbean Popular Culture: Power, Politics and Performance, edited by Yanique Hume \& Aaron Kamugisha (Kingston: Ian Randle, 2016, paper US $\$ 75.00$ ), features a cover painting by Marcel Pinas called Lebi ("red" in his native Ndyuka language)—but they title it Leibi (which is not a word). It is difficult to know for whom this collection of previously-published but mostly-wellselected articles (770 pages worth!) is intended — many are already available to 
students through their university's library/internet subscriptions. How can students, especially in the Caribbean (where both editors teach), be expected to buy a 75-dollar cultural studies reader?

Ethnomusicologist Danielle Brown, whose roots are in Trinidad, has written a memoir of growing up in West Indian Brooklyn: East of Flatbush, North of Love: An Ethnography of Home (New Orleans LA: My People Tell Stories, LLC, 2016, paper US\$25.00). Each section is cued by a song (more than 100, listed on four pages at the outset, and ranging from Kitchener \& Sparrow to Jay Z) that accompanies this account of a changing, gentrifying immigrant community.

Four that we somehow missed earlier: La sublevación de los vecinos de Puerto Rico 1701-1712, by Francisco Moscoso (San Juan: Ediciones Puerto, 2012, paper n.p.), which analyzes an early anticolonial movement of the sort that pitted self-defined criollos against metropolitan authorities throughout the colonial Caribbean; Island Bodies: Transgressive Sexualities in the Caribbean Imagination, by Rosamond S. King (Gainesville: University Press of Florida, 2014), which was published in paperback in 2016 (US\$24.95) and was co-winner of the 2015 Gordon K. and Sybil Lewis Award of the Caribbean Studies Association; Dream Nation: Puerto Rican Culture and the Fictions of Independence, by María Acosta Cruz (New Brunswick NJ: Rutgers University Press, 2014, paper US\$28.95); and Spirited Things: The Work of "Possession" in Afro-Atlantic Religions, edited by Paul Christopher Johnson (Chicago: University of Chicago Press, 2014, paper US\$35.00), which features some excellent chapters—by Stephan Palmié, Kristina Wirtz, Elizabeth McAlister, Karen Richman, Raquel Romberg, and others - on various Caribbean sites (as well as a blurb by RP, calling it "an innovative, stimulating take on Black Atlantic religions"). How we missed that last one when it was published is beyond us.

Harcourt Fuller (Georgia State University) writes that he has recently produced a CD, Granny Nanny Come Oh:Jamaican Maroon Kromanti: and Kumina Music and Other Oral Traditions, featuring The Granny Nanny Cultural Group from Moore Town. The compilation has 31 tracks and a 40-page color booklet with track notes, historical contexts, and photographs. It's available on the internet for US\$19.99.

From the plastic coverings on the sofas through the philandering, drunk husbands, to the recipe for a sancocho prieto that is "an antibomb, a weapon of mass attraction that blasts apart the American concept of the nuclear family," Daring to Write: Contemporary Narratives by Dominican Women, edited by Erika Martínez (Athens: University of Georgia Press, 2016, paper US\$26.95), sparkles with the writing of women, older and younger (some in translation from Spanish), who share Dominican roots. 
Over a five-year period, photographer Dan Goldberg, art director Andrea Kuhn, and food writer Jody Eddy, all from Chicago, made three trips to Cuba, where they discovered a people with "extraordinary spirits and infectious hospitality ... humanity at its best." The result is ;Cuba! Recipes and Stories from the Cuban Kitchen (Berkeley CA: Ten Speed Press, cloth, US $\$ 30.00$ ), whose spectacular color photography (of people, scenes of daily life, and of course food) makes it as appropriate for a living room coffee table as for a kitchen bookshelf.

In another new addition to the seemingly inexhaustible genre of Caribbean cookbooks that tack back and forth between recipes, glossy color photos, and personal anecdotes, Bob Marley's oldest son shares his family's eating habits with us in Ziggy Marley and Family Cookbook (Brooklyn NY: Akashic Books, 2016, Paper US\$24.95). Lots of organic, gluten-free dishes combining traditional Jamaican ingredients and Ital foods with the culinary input of his Israeli wife Orly.

Once again, Rosemarijn Hoefte has provided several interesting paragraphs reviewing Dutch-language books - this year, almost all related to Surinamethat may be of interest to our readers:

Ruud Paesie focuses on the Neptunus slave rebellion in Slavenopstand op de Neptunus: Kroniekvan een wanhoopsdaad (Zutphen, the Netherlands: Walburg Pers, 2016, cloth €19.95). Using new archival evidence, he describes one of the bloodiest revolts in the history of the transatlantic slave trade, claiming an estimated 400 lives. The key question is whether the explosion ending the mutiny in 1785 was an accident or a desperate act. Although Paesie concludes that it was the latter it remains unclear whether this was the act of a single individual or mass suicide. The book sheds ample light on the context of Dutch commercial shipping in general and the slave trade in particular.

P.J. Benoit's Voyage à Surinam from 1839 has been retranslated by Michaël Ietswaart (Zutphen, the Netherlands:Walburg Pers, 2016, paper €19.95). It is not the first re-edition of this popular work; for example, Walburg Pers published a handsome hard copy, with an English summary by Silvia W. de Groot, in 1980 (Reis door Suriname). Ietswaart has modernized the nineteenth-century Dutch, which may make the text more accessible, and the illustrations (the main reason for the work's popularity) are reproduced in vivid colors. The current edition is flawed, however, by poor binding and pages that are too small.

A welcome publication of an older manuscript is G.D. van Wengen's De Javanen in de Surinaamse samenleving (situatie 1960): Berusting en worteling (Rotterdam: Brave New Books, 2016, paper $€$ 22.95), a report on research conducted in Suriname that had only been distributed in mimeograph. This interesting snap-shot of this population group in 1962 complements Annemarie de Waal Malafijt's The Javanese of Surinam: Segment of a Plural Society (1963). 
Astrid Roemer is the first Caribbean author to receive the prestigious P.C. Hooft Prize, a Dutch-language literary lifetime achievement award. Her trilogy on Suriname in the 1980s, Gewaagd leven (1996), Lijken op liefde (1997), and Was getekend (1998), is a monument in Dutch and Caribbean literature. The second part of her autobiography Liefde in tijden van gebrek: Memoires van een thuisloze (Amsterdam: Prometheus, 2016, paper $€ 24.95$ ) is not. This endless and dismal catalog of deceit, fraud, and stolen laptops probably shouldn't have been published.

A very different memoir is by Carib author Reinier Artist who reminisces about his upbringing in Bigi Poika, Suriname, in Indiaans verhaal: In de schaduw van twee beschavingen (Zutphen, the Netherlands: Walburg Pers, 2016, paper $€$ 19.95). In this impressionistic account he lauds the collectivity and egalitarianism of Indigenous society and denounces commercial, religious, and political intruders who always manage(d) to dupe the local population. The most interesting parts are his views on Surinamese history, which are scattered throughout the volume.

An unexpected bestseller in the Netherlands is Frank Krake's Menthol (Hengelo, the Netherlands: Uitgeverij Achtbaan, 2016, paper $€$ 19.95), a partially fictionalized biography of an entrepreneur from St. Lucia named Joseph Sylvester (1890-1955). His life motto was: "follow your heart and your wallet"; therefore, he ended up in the east of the Netherlands, selling toothpaste, a new phenomenon in that part of the world (hence his name Menthol), and falling in love with a Dutch woman. This page-turner tells the story of the first black man in the industrial town of Hengelo through the tribulations of the 1930 s and 1940 .

Another good read is Karin Sitalsing's Boeroes: Een familiegeschiedenis van witte Surinamers (Amsterdam: Atlas Contact, 2016, paper € 21.99) — the history of a group of nineteenth-century Dutch settlers and their descendants. Sitalsing traces the first horrendous experiences of these small farmers (boeroes) and explores their cultural roots.

In Bruine bonen en kouseband: Een biografie van Max Woiski senior en junior (Amsterdam: Nygh en Van Ditmar \& Topnotch, 2016, paper $€ 22.50$ ), Patrick van den Hanenberg tells the history of father and son Woiski, two of the most famous Surinamese musicians in the Netherlands. Max senior (1911-81) and Max junior (1930-2011) popularized Caribbean rhythms in the metropole, but had little influence on the music scene in Suriname.

Finally (if we may adopt the third person momentarily), Richard \& Sally Price have brought out two new translation/adaptations of Two Evenings in Saramaka (1991)—Boo go a kontukonde, in Saamakatongo, and Deux soirées de contes saamaka, in French (both La Roque d'Anthéron: Vents d'ailleurs, 
2016, paper $€ 18.00$ and $€ 22.00$ respectively). They also published Boléro tropical (New York: Libriso, 2016, US\$16.oo, available world-wide on the Espresso Book Machine), a French translation/adaptation of their Harvard University Press novel, Enigma Variations (1995). And Vents d'ailleurs has published a second French edition of RP's Martiniquan memoir, Le bagnard et le colonel (2016, paper $€ 24.00$ ), with a new afterword.

We end this year's Bookshelf by listing information on titles that we have noticed but neither examined nor requested for review-in some cases because their Caribbean content is restricted to a chapter or two, in others because they didn't seem sufficiently compelling given NWIG space limitations, or for a variety of other reasons. Together, they testify to the large number of books being published that at least touch on the Caribbean.

Presencia negra en la cultura cubana: Lecciones introductorias, edited by Leidys Dominguez Camejo (Havana: Editorial Sensemayá, 2016, paper n.p.)

Memoir of My Youth in Cuba: A Soldier in the Spanish Army during the Separatist War, 1895-1898, by Josep Conangla, edited by Joaquín Roy (Tuscaloosa: University of Alabama Press, 2017, paper US\$34.95)

De la mano de changó: Perfil histórico de la Ocha (santería cubana), 1825-1944, by Ricardo J. Solis Herrera (Mexico DF: Universidad Nacional Autónoma de México, 2015, paper US\$13.99)

Cubanisms: A Nostalgic Look at Cuba through Art and Words, by Pedro Menocal (author) \& Pablo Cano (illustrator) (Coral Gables FL: Mango, 2016, paper US\$19.95)

Cuban Music in Revolution: 7o Years of Cuban Record Cover Art, edited by Stuart Baker (London: Soul Jazz Books, 2016, cloth US\$ 49.95)

Cast in Deathless Bronze: Andrew Rowan, the Spanish-American War, and the Origins of American Empire, by Donald Tunnicliff Rice (Morgantown: West Virginia University Press, 2017, paper US\$27.99)

Education in Mexico, Central America and the Latin Caribbean, edited by C.M. Posner, Christopher Martin \& Colin Brock (London: Bloomsbury Academic, 2017, cloth US\$172.00)

How the CIA Killed Che: The Murder of a Revolutionary, by Michael Ratner \& Michael Steven Smith (New York: Skyhorse, 2016, cloth US\$22.95)

CUBA: Diary of a Revolution, Inside the Cuban Revolution with Fidel, Raul, Che, and Celia Sanchez, by Deena Stryker (Oakland CA: Next Revelation Press, 2016, cloth US\$34.99)

Human Rights in Cuba, El Salvador and Nicaragua: A Sociological Perspective on Human Rights Abuse, by Mayra Gomez (London: Routledge, 2016, paper US\$47.95)

Ciencia y poder en Cuba: Racismo, homofobia, naciòn (1790-1970), by Pedro Marqués de Armas (Madrid: Verbum, 2014, paper US\$36.95) 
Ifá Divination, Knowledge, Power, and Performance, edited by Jacob K. Olupona \& Rowland O. Abiodun (Bloomington: Indiana University Press, 2016, paper US\$40.oo)

Cuba's Baseball Defectors: The Inside Story, by Peter C. Bjarkman (Lanham MD: Rowman \& Littlefield Publishers, 2016, cloth US\$36.oo)

Cuba's Car Culture: Celebrating the Island's Automotive Love Affair, by Tom Cotter \& Bill Warner (London: Motorbooks, 2016, cloth US\$35.00)

Fronteras de agua: Las ciudades portuarias y su universo cultural (siglos xiv-xxi), edited by Manuel Reyes García Hurtado \& Ofelia Rey Castelao (Santiago de Compostela, Spain: Universidade de Santiago de Compostela/La Coruña, Spain: Universidade da Coruña, 2016, paper n.p.)

La rabia útil de los muertos (Una novela de zombis), by Ángel A. Rivera (San Juan: Editorial Disonante, 2016, paper US\$15.95)

Intemperie, by Eduardo Lalo (Buenos Aires: Corregidor, 2013, paper n.p.) [essays on Puerto Rico and writing]

Vieques y Culebra: Tesoros del archipiélago, by Víctor Manuel Nieves (Guaynabo, PR: Impressive Publications, 2015, cloth US\$45.00) [photos]

El Club Tanamá: La invisibilización del hombre y la mujer negros por el independentismo puertorriqueño, by Daniel Nina (San Juan: Isla Negra Editores \& Pasillo del Sur Editores, 2016, n.p.)

Through the Eyes of Rebel Women: The Young Lords, 1969-1976, by Iris Morales (New York: Red Sugarcane Press, 2016, paper US\$25.00)

Rompe Saragüey, by Daniel Nina (San Juan: Isla Negra Editores \& La Mágica Editores, 2016, paper US\$ n.p.)

Spanish-English Codeswitching in the Caribbean and the US, edited by Rosa E. Guzzardo Tamargo, Catherine M. Mazak \& M. Carmen Parafita Couto (Amsterdam: John Benjamins, 2016, cloth US\$149.00)

A Reader in African-Jamaican Music, Dance and Religion, edited by Markus Coester \& Wolfgang Bender (Kingston: Ian Randle, 2014, paper US\$49.95)

The UWI Gender Journey: Recollections and Reflections, by Joycelin Massiah, Elsa LeoRhyni \& Barbara Bailey (Kingston: University of the West Indies Press, 2016, paper US\$40.00)

The Marcus Garvey and Universal Negro Improvement Association Papers, Volume XIII: The Caribbean Diaspora, 1921-1922, edited by Robert A. Hill (Durham NC: Duke University Press, 2016, cloth US\$120.00)

Jamaica in the 21st Century: Revisiting the First Decade, by Livingstone Thompson (Lanham MD: University Press of America, 2016, paper US\$26.99)

Slavery, Geography and Empire in Nineteenth-Century Marine Landscapes of Montreal and Jamaica, by Charmaine A. Nelson (London: Routledge, 2016, cloth US\$149.95) Reggae from Yaad: Traditional and Emerging Themes in Jamaican Popular Music, edited by Donna P. Hope (Kingston: Ian Randle, 2015, paper US\$22.95) 
50 Favorite Jamaican Recipes: Taste the Islands Essentials, by Calibe Thompson (n.p.: CreateSpace, 2016, paper US\$19.99)

Criminal Enterprises and Governance in Latin America and the Caribbean, by Enrique Desmond Arias (Cambridge: Cambridge University Press, 2016, cloth US\$99.99) [about Rio, Medellín, and Kingston]

Learning in Womanist Ways: Narratives of First Generation African Caribbean Women, by Jan Etienne (Stoke-on-Trent, U.K.: Trentham Books, 2016, paper US\$32.95)

Sport in the Black Atlantic: Cricket, Canada and the Caribbean Diaspora, by Janelle Joseph (Manchester, U.K.: Manchester University Press, 2016, cloth US\$90.oo)

Crime and Security in Trinidad and Tobago, by Randy Seeperdsad \& Williams Dianne (Kingston: Ian Randle, 2016, paper US\$22.95)

The Hindu View of Trinidad and Tobago: Selected Articles by Sat Maharaj, vol. 1, edited by Kumar Mahabir (Saint Augustine, Trinidad: Sanatan Dharma Maha Sabha, 2016, n.p.)

From Innocence to Impudence, by Awadh Jaggernath (Oakville ON, Canada: Mosaic Press, 2016, paper US\$16.64) [growing up in Trinidad]

Travels with a Husband, by Patricia Mohammed \& Rex Dixon (Hertford, U.K.: Hansib, 2016, paper £15.99)

Returned Exile: A Biography of George James Christian of Dominica and the Gold Coast, 1869-1940, by Margaret D. Rouse-Jones \& Estelle M. Appiah (Kingston: University of the West Indies Press, 2016, paper US\$40.0o)

Contradictory Existence: Neoliberalism and Democracy in the Caribbean, edited by David Ramsaran (Kingston: Ian Randle, 2016, paper US\$18.95)

Creolizing Hegel, edited by Michael Monahan (London: Rowman \& Littlefield International, 2017, cloth US\$135.00)

Chronique de la Décadanse du Chef Suprême, by Castro Desroches (n.p.: CreateSpace, 2016, paper US\$25.00)

Close Your Eyes, Now Breathe, by Flose Boursiquot (n.p.: CreateSpace, 2017, paper US\$12.99) [poetry by a Haitian-born Florida resident]

Frantz Fanon: Figure emblématique duxxe siècle à l'épreuve du temps, edited by Maurice Amuri Mpala-Lutebele \& Antoine Tshitungu Kongolo (Paris: L'Harmattan, 2016, paper $€ 37.50)$

Amour, sexe, genre et trauma dans la carä̈be francophone, edited by Gladys Francis (Paris: L'Harmattan, 2016, paper €29.00)

Jewish Treasures of the Caribbean: The Legacy of Judaism in the New World, by Wyatt Gallery (Atglen PA: Schiffer, 2017, cloth US\$6o.oo) [photos]

Understanding ALBA: The Progress, Problems, and Prospects of Alternative Regionalism in Latin America and the Caribbean, edited by Asa Cusack (London: Institute of Latin American Studies, 2017, paper US\$40.0o)

Climate Change and Food Security: Africa and the Caribbean, edited by Elizabeth Thomas Hope (London: Routledge, 2017, cloth US\$145.00) 
Saba's First Inhabitants: A Story of 3300 Years of Amerindian Occupation Prior to European Contact (180о BC-AD1492), by Corinne Hofman \& Menno Hoogland (Leiden, the Netherlands: Sidestone Press, 2016, paper US\$20.00)

Handbook of Ceramic Animal Symbols in the Ancient Lesser Antilles, by Lawrence Waldron (Gainesville: University of Florida Press, 2016, cloth US\$125.00)

A Universal Theory of Pottery Production: Irving Rouse, Attributes, Modes, and Ethnography, by Richard A. Krause (Tuscaloosa: University Alabama Press, 2016, cloth US\$54.95)

The Tutu Archaeological Village Site: A Multi-Disciplinary Case Study in Human Adaptation, edited by Elizabeth Righter (London: Routledge, 2016, paper US\$47.95) [the site is on St. Thomas]

Islas Migajas: Los países no independientes del Caribe contemporáneo, by Aarón Gamaliel Ramos (San Juan: Travesier \& Leduc Editores, 2016, paper US\$25.00)

Intimate Partner Violence and Advocate Response: Redefining Love in Western Belize, by Melissa Beske (Lanham MD: Lexington Books, 2016, cloth US\$80.0o)

Historical Dictionary of the Dominican Republic by Eric Paul Roorda (Lanham MD: Rowman \& Littlefield, 2016, cloth US\$105.00)

Imagining Asia in the Americas, edited by Zelideth Maraia Rivas \& Debbie Lee-DiStefano (New Brunswick NJ: Rutgers University Press, 2016, cloth US\$27.95)

Re-Imagining Community and Civil Society in Latin America and the Caribbean, edited by Roberta Rice \& Gordana Yovanovich (London: Routledge, 2016, cloth US\$140.00) Decolonizing Democracy: Power in a Solid State, by Ricardo Sanín-Restrepo (London: Rowman \& Littlefield International, 2016, paper US\$39.95)

A Cultural History of Underdevelopment: Latin America in the U.S. Imagination, by John Patrick Leary (Charlottesville: University of Virginia Press, 2016, paper US\$35.00)

A Short History of U.S. Interventions in Latin America and the Caribbean, by Alan McPherson. (Hoboken NJ: Wiley-Blackwell, 2016, paper US\$29.95)

African American Contributions to the Americas'Cultures: A Critical Edition of Lectures by Alain Locke, edited by Jacoby Adeshei Carter(Basingstoke, U.K.: Palgrave Macmillan, 2016, cloth US\$90.0o)

The Royal Navy and the British Atlantic World, c. 1750-1820, edited by John McAleer \& Christer Petley (Basingstoke, U.K.: Palgrave Macmillan, 2016, cloth US\$9o.oo)

Mountain Majesty: The History of CODEP Haiti-Where Sustainable Agricultural Development Works, by John V. Winings (n.p.: Dudley Court Press, 2016, paper US\$16.99) 